\title{
Macroecology of North European Wet Grassland Landscapes: Habitat Quality, Waders, Avian Predators and Nest Predation
}

\author{
Michael Manton ${ }^{1}$ (D) and Per Angelstam ${ }^{2,3, *}$ \\ 1 Faculty of Forest Science and Ecology, Vytautas Magnus University, LT-53361 Akademija, Lithuania; \\ michael.manton@vdu.lt \\ 2 Department of Forestry and Wildlife Management, Campus Evenstad, \\ Inland Norway University of Applied Sciences, N-2480 Koppang, Norway \\ 3 School for Forest Management, Swedish University of Agricultural Sciences, P.O. Box 43, \\ SE 73921 Skinnskatteberg, Sweden \\ * Correspondence: per.angelstam@inn.no
}

Citation: Manton, M.; Angelstam, P. Macroecology of North European Wet Grassland Landscapes: Habitat Quality, Waders, Avian Predators and Nest Predation. Sustainability 2021, 13, 8138. https://doi.org/10.3390/ su13158138

Academic Editors: Marc A. Rosen and Richard H. Loyn

Received: 21 May 2021

Accepted: 18 July 2021

Published: 21 July 2021

Publisher's Note: MDPI stays neutral with regard to jurisdictional claims in published maps and institutional affiliations.

Copyright: (c) 2021 by the authors. Licensee MDPI, Basel, Switzerland. This article is an open access article distributed under the terms and conditions of the Creative Commons Attribution (CC BY) license (https:/ / creativecommons.org/licenses/by/ $4.0 /)$.

\begin{abstract}
Wet grassland degradation is a global issue that involves both altered land cover patterns and ecological processes, which affect the distribution and abundance of species. The sharp decline in European wader bird (Charadrii) populations is a good example. The aim of this study is to test the hypothesis that the anthropogenic developmental stage of wet grassland habitats and landscapes drives avian nest predator abundance, and thus the predation pressure on nests, which is a major cause of wader bird declines. Using a macroecological approach we selected six wet grassland landscapes representing a gradient in both grassland habitat development and breeding wader population status in four European countries (Belarus, Iceland, Lithuania and Sweden). We (1) mapped wader and avian predator assemblages in multiple wet grassland patches in each landscape, (2) used artificial nests to estimate the relative rate of egg predation, and (3) analyzed relationships between nest predation pressure, corvid nest predators versus raptors, nest loss and the stage of wet grassland habitat and landscape development. We found (1) inverse relationships between the abundance of corvids and waders, as well as between wet grassland developmental stage and waders, and (2) a positive correlation between the probability of nest loss and the density of corvid birds. In conclusion, we found a clear macroecological pattern linking habitat quality, wader populations, nest predators and nest predation. These linkages stress the importance of including nest predation as a factor limiting wader bird populations, and that corvid control or management may be useful management tools.
\end{abstract}

Keywords: corvid birds; case study; habitat quality; pattern; process; raptors; wader bird

\section{Introduction}

Wet grasslands in Europe have a long history of human-induced land use and land cover change [1-3]. Being biologically productive, naturally dynamic wet grasslands were extended by humans for increased animal husbandry. Grazing and traditional hay making on naturally periodically flooded wet grasslands thus expanded, and resulted in a cultural landscape that provided favourable habitat for wader birds [3,4].

Due to dramatic changes in land use over the past century, today grasslands of different kinds are one of the most degraded and threatened ecosystems $[3,5,6]$. A range of human-induced factors, including intensification of agriculture $[7,8]$, hydrological changes [9], eutrophication [10], land abandonment [11], forest expansion [12], urbanization [13] and climate change [14], are drivers of wet grassland degradation.

These drivers have resulted in land cover changes that have directly and indirectly influenced species' habitats, and thus the composition and structure of species assemblages $[15,16]$. The degradation of wet grasslands is paralleled by declines in breeding 
populations of wader birds (Charadrii). In a compilation of breeding wader bird population trends in Europe, Thorup [17] found that 18 out of 68 species were in significant decline. Among these declining wader populations seven species are known to breed on wet grasslands: Dunlin (Calidris alpina), Black-tailed Godwit (Limosa limosa), Redshank (Tringa totanus), Great Snipe (Gallinago media), Common Snipe (Gallinago gallinago), Lapwing (Vanellus vanellus), and Ruff (Philomachus pugnax). Wader population declines have been recorded in wet grassland areas with both small and large populations, for instance in Sweden [18] and the Netherlands [14], respectively. Declines in breeding wader populations in southern Sweden have continued at both regional [19] and local scales [20,21]. However, the role of habitat loss for wader birds in anthropogenic wet grasslands in northern Europe is not a new phenomenon. Already in 1858, Nilsson [22] reported declines in Black-tailed Godwit populations on the Swedish island of Gotland, and attributed this to draining of the wet grasslands to increase the area of farmland.

The quantity and quality of wet grassland habitat patches has thus been severely reduced in most of Europe [9,15], but there are also regions with intact and even increasing amounts of suitable habitat for wader birds [15]. To explain this, the effects of both pattern and process in entire landscapes need to be considered $[23,24]$. The spatial pattern of land cover patches is a vital component affecting the state and trends of biodiversity and ecosystem dynamics [25]. Land cover patterns in landscapes are affected by patch quality, size and quantity, as well as spatial configuration of patches including connectivity and fragmentation [26,27]. Additionally, changes in ecological processes at multiple scales from within patches to landscapes also need to be considered [28,29]. Because the abundance of predators may affect prey species populations, predator-prey interactions are a good example [20,30]. For wader birds, Roodbergen, Werf and Hötker [14] reviewed data about reproductive output and adult survival, and found that wader population declines were caused by decreased reproductive success and not adult survival.

Avian nest predator abundance parallels land use intensity and land cover changes, which increase the availability of anthropogenic food resources, [31,32]. The abundance of avian predators and associated predation pressure affects the distribution and abundance of breeding ground nesting bird assemblages, such as waders [20,33,34]. This contributes to higher nest predation rates, declines in breeding wader populations and even local extinctions $[17,35,36]$. The hypothesis that predation on eggs and fledglings of nesting waders' limits wader populations $[15,33,37,38]$ stresses the need to compare the abundance of both wader birds and different types of avian predators, as well as the predation pressure on wader bird nests among multiple wet grassland landscapes representing different contexts and development stages.

The combination of past legacies and current land management regimes in Europe has created regionally specific ecological, economic and socio-cultural contexts. This can be used as a 'time machine' [39-41] to help understand the effects human society has on the patterns and processes of ecosystems. The diversity in land use history within the European continent thus provides ample opportunity for replicated studies in wet grasslands with different landscape-predator-prey relationships [42]. However, studies exploring the effects of predation on wet grassland wader birds that use multi-scale analysis of patch, landscape and regions are largely missing.

There are several reasons for this. First, in highly modified landscapes it can be challenging to realise how much they have already changed [43-45]. This phenomenon of shifting base lines makes conservation objectives fundamentally difficult to achieve because of the lack of long-term data [43]. However, this can be dealt with through replicated studies of landscapes with different environmental and political histories [42]. Second, while patterns such as the quality, size and configuration of land cover patches are easy to measure, a process such as predation is less straightforward to estimate. This difficulty can be handled through simultaneous studies of the focal species group, such as wader bird assemblages in this case, their avian predators, and the predation rates in landscapes with different land use histories. 
The aim of this study is to test the hypothesis that avian nest predator abundance and nest predation pressure is positively related to the developmental stage (i.e., habitat quality) of wet grassland landscapes: from emerging to functioning to degraded. We thus employed a macroecological approach using six different wet grassland landscapes, representing a gradient in factors driving breeding habitat quality (e.g., the combination and degree of ecological and hydrological functionality and degree of human impact) and wader population status (declining, stable and increasing) in four European countries. We (i) described the wader bird and avian nest predator assemblages for each landscape, and

(ii) made an exploratory study to test the hypothesis that nest predator abundance, and predation pressure are positively correlated.

\section{Materials and Methods}

\subsection{A Macroecological Approach with Multiple Case Studies}

To understand predation-prey relationships affecting the composition and structure of wader bird assemblages, three spatial scales need to be explored, [46-48]: (1) within local habitat patches of breeding wader birds [26,49], (2) within the broader landscapes of focal avian predator species [42,50], and (3) within regions that have different landscape histories [51]. Therefore, we applied a macroecological approach [52] that trades off the precision of small-scale research within individual local landscapes [53,54], with broader regional contexts $[39,52]$.

The use of multiple landscapes as case studies provides a strategy that focuses on understanding the dynamics within both singular and multiple settings and across multidisciplinary sciences [55-57]. The distinguishing aspect of a macroecological case study approach is that it can explore a contemporary phenomenon in its actual context, especially when the limitations between phenomenon and context are not visible [58]. Therefore, the use of multiple landscapes as case studies linking social and ecological systems to investigate, test hypotheses and compare results of similarly and differently managed land covers and the subsequent outcomes is an appropriate method to study the complexity of waders, avian predators and different land covers.

\subsection{Northern Europe as a Landscape Laboratory}

Countries with less intensive land management histories still host species that are often locally extinct or declining in countries with intensified land management practices [42,59-63]. This applies to both cultural landscapes and natural forests landscapes [40]. Additionally, there are regions where the amount of habitat is increasing due to the emergence and expansion of otherwise declining habitats [15]. The north European context presents unique opportunities to apply a macroecological approach.

To represent wet grassland landscape developmental stages (e.g., the combination and degree of ecological and hydrological functionality and degree of human impact) from emerging due to active management, to supporting animal husbandry, to functioning, and finally to degraded, we identified six case study landscapes in four European countries with different landscape histories, wet grassland developmental stages (i.e., habitat quality), wader and avian predator assemblages, and wader population statuses (Figure 1, Table 1). 


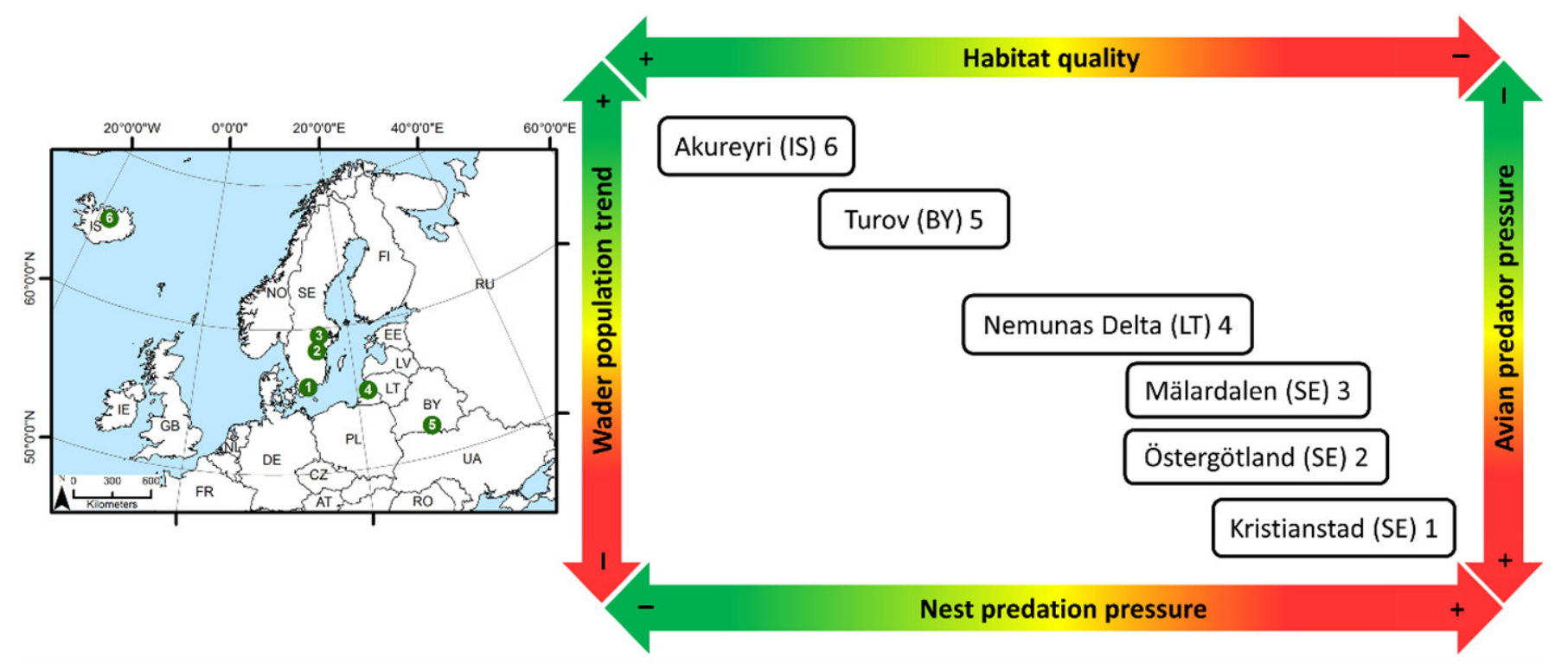

Figure 1. Overview of the six selected wet grassland landscapes in Northern Europe (left), and a macroecological design of the selected wet grassland landscapes. Using the traffic light approach each axis represents the status of the variable. The left axis shows the status of local wader populations (declining, stable and increasing). The top axis represents the gradient in breeding habitat quality, which refers to the wet grassland development stage (e.g., a combination of degree of ecological and hydrological functionality and degree of human impact). The right axis represents the diversity and abundance of avian predators. The bottom axis represents nest predation pressure on wader birds. A summary of the six wet grassland case study landscapes' characteristics can be found in Table 1.

Table 1. Overview characteristics of the six wet grassland case study landscapes from four countries in Northern Europe.

\begin{tabular}{|c|c|c|c|c|c|c|}
\hline $\begin{array}{l}\text { Case Study } \\
\text { Landscapes }\end{array}$ & Kristianstad & Östergötland & Mälardalen & Nemunas Delta & Turov & Akureyri \\
\hline Country & Sweden & Sweden & Sweden & Lithuania & Belarus & Iceland \\
\hline Development index & 5 & 4 & 4 & 3 & 2 & 1 \\
\hline $\begin{array}{c}\text { Trend in grassland } \\
\text { habitat }\end{array}$ & Strong decline [49] & Decline [21] & Decline $[64,65]$ & Slight decline [66] & Stable [66] & Increase [66] \\
\hline Wader trends & Negative [20] & Negative [21] & Negative [67] & Declining [68] & Stable [68] & Increase [15] \\
\hline $\begin{array}{c}\text { \# of wet grassland } \\
\text { patches }\end{array}$ & 21 & 22 & 27 & 37 & 30 & 31 \\
\hline Total area (ha) & 1288 & 726 & 1486 & 2698 & 2135 & 1196 \\
\hline Mean Patch size (ha) & 61 & 33 & 55 & 73 & 71 & 39 \\
\hline Patch size range (ha) & $15-168$ & $6-153$ & $18-134$ & $24-133$ & $23-219$ & $7-174$ \\
\hline Standard Deviation & 36 & 33 & 32 & 29 & 43 & 34 \\
\hline
\end{tabular}

\subsection{Six Case Studies in a Gradient of Landscape Change \\ 2.3.1. Sweden}

Lindström and Green [19] found that Swedish regional wader population trends during 1998-2012 increased by $2 \%$ per annum in the north. However, for the same period, they found a 3.5\% decline in southern Sweden. This is linked to the different types of wet grassland habitats. In northern Sweden, wader bird populations depend on near-natural systems, such as mountain and boreal wetlands [69], which have remained intact as they have not been subject to land use intensification. In contrast, southern Sweden only hosts small fragments of once abundant anthropogenic wet grassland landscapes [45,49]. To represent landscapes where wader bird habitat and populations are declining, we selected three case study landscapes in southern Sweden (Figure 1). These were three hotspots for wet grassland habitat for wader bird conservation [70,71], namely (1) Kristianstad 
Vattenrike Biosphere Reserve (approx. $56^{\circ} 00^{\prime} \mathrm{N}, 14^{\circ} 13^{\prime} \mathrm{E}$ ); (2) Östergötland County (approx. $58^{\circ} 29^{\prime} \mathrm{N}, 15^{\circ} 35^{\prime} \mathrm{E}$ ); and (3) the Mälardalen area in the river catchment of Norrström (approx. $59^{\circ} 28^{\prime} \mathrm{N}, 16^{\circ} 41^{\prime} \mathrm{E}$ ). The three Swedish case study landscapes contain small remnants of semi-natural grassland patches, with similar past histories of hay-making and grazing [65]. Historically, under traditional land use systems, these landscapes hosted large and stable wader bird species populations [20,21]. However, today these landscapes are dominated by intensively managed arable fields. Some remnants of wet grassland patches have been subject to restoration efforts to maintain species related to traditional agricultural management through short term environmental schemes to undertake mowing and grazing [72,73].

\subsubsection{Lithuania and Belarus}

In countries of the former Soviet Union, land use intensification commenced later compared to Europe's west, and biodiversity has so far been better maintained [40,74]. Focusing on remnants of wet grasslands that have a better ecological status than the Swedish wet grasslands, we selected one landscape in Lithuania and another in Belarus.

In Lithuania, we selected the seasonally flooded wet grassland landscape of the Nemunas River Delta $\left(55^{\circ} 18^{\prime} \mathrm{N}, 21^{\circ} 20^{\prime} \mathrm{E}\right)$ which is one of the largest in the Baltic Sea Region. The annual inundation on this lowland floodplain ( $30,000 \mathrm{ha}$ ) generally lasts for 60 days during spring, although it is not uncommon to become flooded during other times of the year. The main land use activities are cattle grazing and hay production. However, due to the flooding these management operations are conducted later in the growing season than in other parts of Lithuania [75]. This contributes to the importance of the Nemunas River Delta as a breeding ground for wader species in the Baltic Sea region [76,77]. Nevertheless, wader birds have declined in recent years through the abandonment of traditional land management practices [78].

The Pripyat floodplain in southern Belarus contains a contiguous band of wet grasslands that still maintain patterns and processes characteristic of cultural wetlands in a seasonally flooded shallow river valley [6]. These wet grasslands are used as a reference and benchmark for wet grassland restoration in other countries [6]. We selected the wet grassland landscape of the mid Pripyat valley surrounding the small town of Turov in the central part of the Polessie lowlands $\left(52^{\circ} 4^{\prime} \mathrm{N}, 27^{\circ} 44^{\prime} \mathrm{E}\right)$. Natural flooding of the 9-km wide wet grassland floodplain that stretches through the mid Pripyat valley is common during spring, summer and autumn. As a result, large wet grasslands at Turov form suitable habitat for breeding waders, as well as an important stopover for waders migrating on the eastern Atlantic migration flyway [79].

\subsubsection{Iceland}

In contrast to all other parts of Europe, the wader populations in Iceland are thriving. Indeed, Iceland supports internationally important breeding populations of 10 wader species, and for some of these Iceland hosts a substantial proportion of the world population [80]. Estuaries, grasslands and coastal shores provide natural habitats for waders in Iceland [81]. However, lowland regions of Iceland have undergone significant drainage with the conversion of wetlands to agricultural land in recent decades [82]. This has increased the area extent of grasslands aimed at producing feed for dairy cows, juxtaposed with estuaries and natural grasslands [15]. This is associated with increasing numbers of some wader species. For example, while the size of Western European populations of Black-tailed Godwits has declined rapidly, the Icelandic population has undergone a rapid increase.

We chose the coastal lowlands around Akureyri in Northern Iceland as a case study landscape $\left(65^{\circ} 43^{\prime} \mathrm{N}, 18^{\circ} 07^{\prime} \mathrm{E}\right)$. Low agriculture intensity in the past can be attributed to the environmental constraints of high latitudes, with factors such as short growing seasons and a lack of topsoil limit opportunities, as well as the topology [83]. However, with national 
support for agriculture and milk production, semi-natural grasslands have developed for intensive hay production.

\subsection{Waders, Avian Predators and Predation Pressure}

During the phase of territorial establishment in the beginning of the breeding period (e.g., April-June) in the individual landscapes, we visited a sample of wet grassland patches ( $\mathrm{N}=21-37$ sized 6-220 ha) in each of the six case study landscapes once in 2013-2016 (Table 1). We counted all wader birds, as well as both corvid birds and raptors within the wet grassland patches. At each wet grassland patch, we conducted a count sweep using binoculars and a spotting scope. Field work was undertaken from dawn to midday under favourable weather conditions (i.e., neither rainy nor windy).

\subsection{Artificial Nest Predation as Proxy of Predation Pressure}

The use of artificial nest experiments has been strongly debated. On the one hand, comparisons of artificial and real nests do not measure actual rates of nest predation and are thus often discouraged [84-86]. However, on the other hand, explorative artificial nest predation experiments have proven useful to estimate the relative level and variation in predation pressure associated with characteristics of eggs, nests, habitat, location, density, season and the identification of predators and factors influencing predator activity $[32,87-90]$. The purpose of using artificial nests in this study is to gain exploratory knowledge about the processes affecting natural nests and to estimate the potential relative impacts of predation on an avian assemblage [38,91,92]. Therefore, following Pehlak and Lõhmus [37], we placed artificial wader nests in five randomly selected wet meadow habitat patches suitable for wader breeding. In each landscape case study area, the nests were exposed for a period of ten days during the wader breeding season in 2013 (Kristianstad and Östergötland), 2014 (Nemunas Delta and Turov) and 2015 (Mälardalen). Within each habitat patch, 10 artificial wader nests containing two small brown chicken eggs (i.e., $n=50$ per stratum in each case study landscape) were placed at night (2300-0300 h), [c.f., 32], in microsites with open vegetation height varying between $0-30 \mathrm{~cm}$, and at a minimum distance of $100 \mathrm{~m}$ from each other. The placement of eggs at night was undertaken to avoid attention from curious corvid predators. However, we were aware that this might also draw the attention of mammal predators [93]. Nest locations were recorded using a GPS and a stick $(40 \mathrm{~cm} \times 0.5 \mathrm{~cm})$ placed $3 \mathrm{~m}$ to the north of the nest. The aim was to simulate wader nests, which are simply eggs laid on the ground. Each nest was then inspected for predation during the night after 5 and 10 days, respectively. A nest was considered as having been preyed upon if either one or both eggs were broken or missing. At each predated nest, an inspection was conducted to identify the perpetrator $[92,94]$. The daily probability of survival of artificial nests was calculated using the method of Mayfield [95]. Unfortunately, the artificial nest predation study was unsuccessful on Iceland as the methodological procedures were not able to be replicated, because in the Arctic Circle during breeding season there is no darkness at night. During our attempts we noticed the curiosity of the local corvids who followed us, inspected our nests and prey upon the eggs.

\section{Results}

\subsection{Waders and Predators in the Macroecological Gradient}

The abundance of waders and avian predators (corvids and raptors) varied inversely among the six case study landscapes, with Kristianstad hosting the lowest number of waders but the highest number of both corvids and raptors (Figure 2; Table 2; Supplementary Material Table S1). 


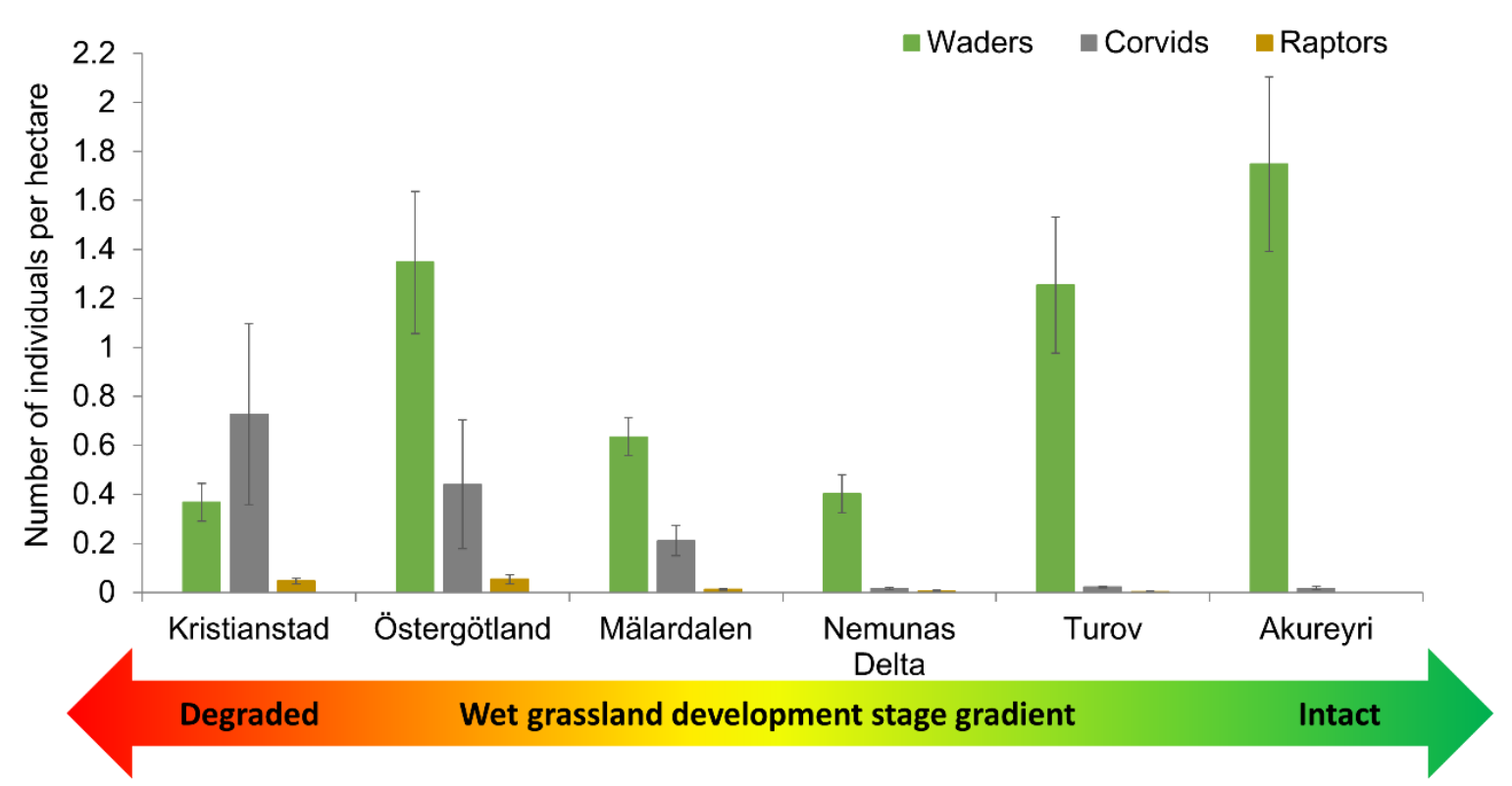

Figure 2. Mean number of waders, corvids and raptors observed per hectare for the six case study wet grassland landscapes in northern Europe (see Figure 1).

Table 2. Mean number of waders and avian predators in six case study landscapes in northern Europe.

\begin{tabular}{ccccccc}
\hline Case Study Landscapes & Kristianstad & Östergötland & Mälardalen & Nemunas Delta & Turov & Akureyri \\
\hline Waders & 14.33 & 23.95 & 27.04 & 28.08 & 62.80 & 35.6 \\
\hline Corvids & 25.00 & 5.77 & 9.00 & 0.97 & 1.30 & 0.35 \\
\hline Raptors & 2.48 & 1.18 & 0.67 & 0.41 & 0.30 & 0.00 \\
\hline
\end{tabular}

The number of wader bird species was similar among the landscapes in the wet grassland development gradient (Spearman Rho rank $\mathrm{r}=0.61, n=6, p=0.09$, i.e., onetailed), ranging from nine in Kristianstad and Mälardalen in Sweden to 12 in Akureyri and 13 in Turov. In contrast, the total abundances of avian predator species declined along the wet grassland developmental stage gradient (from emerging via functioning to degraded) (Spearman Rho $\mathrm{r}=-0.82, n=6, p=0.02$, one-tailed). The number of corvid species ranged from five in Kristianstad to one in Akureyri, where Northern Ravens (Corvus corax) are the only resident corvid species. There was a significant negative relationship between the number of individual corvids and waders (Spearman Rho rank $\mathrm{r}=-0.79, n=6, p=0.03$, one-tailed; log transformed). The number of raptor species ranged from 0 in Akureyri to 6 in Kristianstad and did not show a significant relationship between the number of raptors and waders (Spearman Rho rank $\mathrm{r}=-0.64, n=6, p=0.09$, one-tailed; $\log$ transformed). The ratios between the number of corvid and wader individuals, and raptors and wader individuals, respectively, were both negatively related to the landscape gradient between Kristianstad and Akureyri (Spearman Rho $\mathrm{r}=-0.94, n=6, p=0.003$, one-tailed; Spearman Rho $\mathrm{r}=-0.99, n=6, p=0.0002$, one-tailed; Figure 3). 

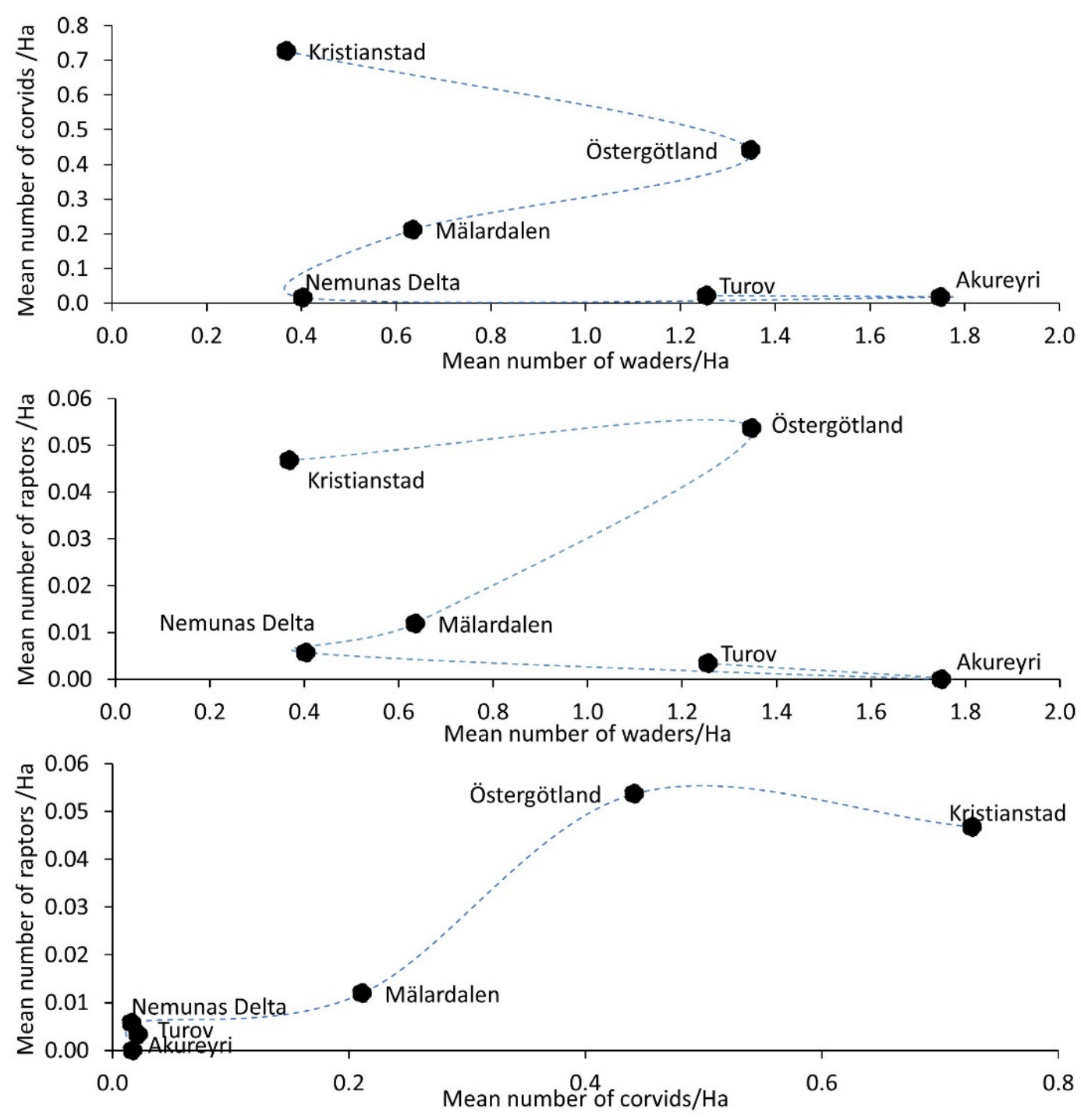

Figure 3. Relationships between waders and corvid predators (top), waders and raptors (middle) and corvids and raptors (bottom). The connecting lines show the progression of the wet grassland development stage gradient (see Figure 1).

\subsection{Artificial Nest Predation}

Overall corvid birds were a major predator of nests (38\%), where the artificial nest experiments were made (i.e., not in Akureyri, due to our failed attempt) (Figure 4). Mammals accounted for $4 \%$ and non-predator reasons (trampling by cows and farm machinery) accounted for $15 \%$. The category 'unknown' made up $43 \%$ of cases. Across the five landscapes from Kristianstad to Turov there was a clear negative trend in terms of the proportion of unknown reasons for nest loss versus nest loss caused by corvids (Spearman Rho $=-0.999, n=5, p=0.001$. 


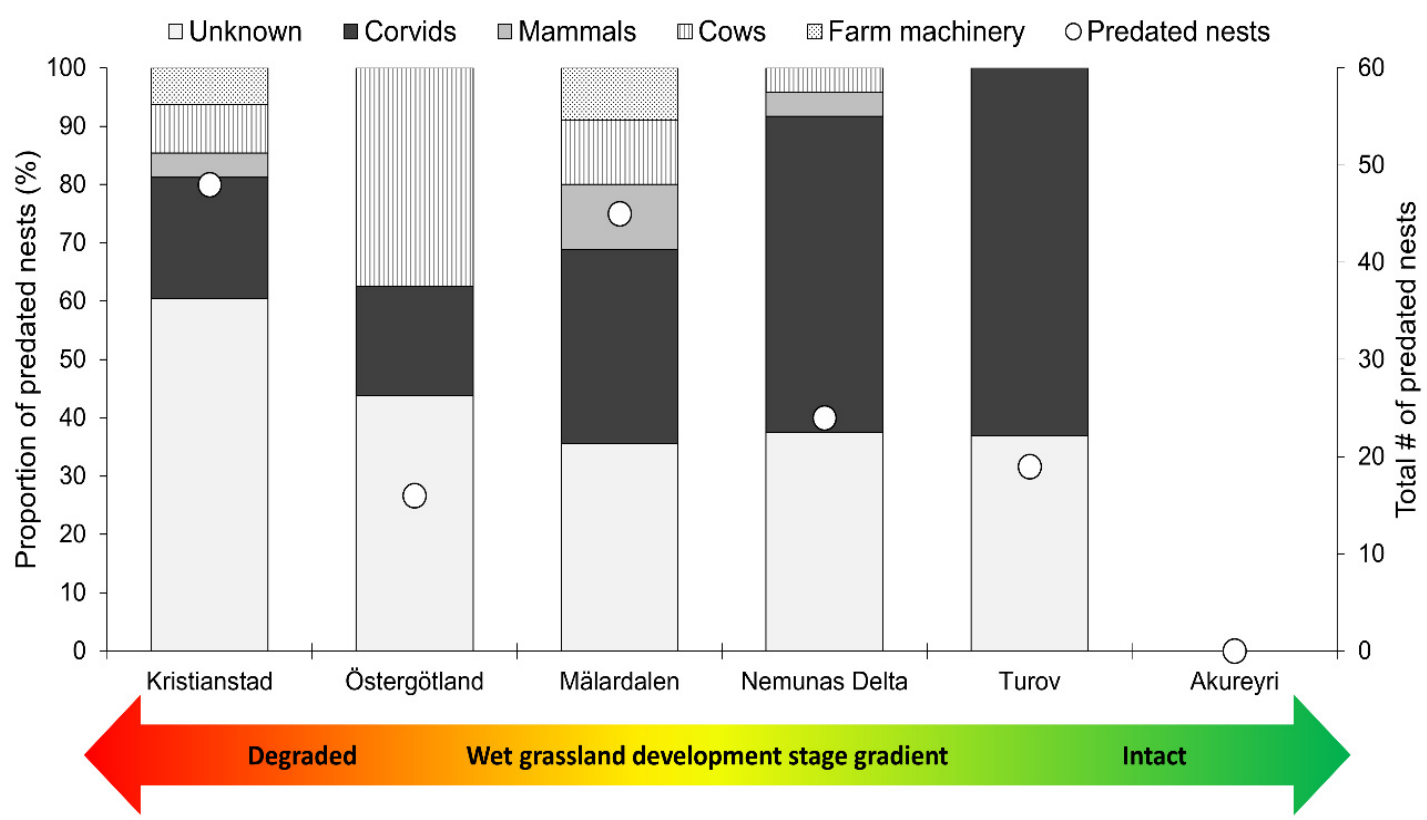

Figure 4. Proportions of the artificial ground nests preyed upon divided by the reasons for loss of artificial nests (bars and left vertical axis) and the total predation number in northern Europe (point and right vertical axis) (see Figure 1). Note: the nest predation experiment failed in Akureyri.

The daily probability of nest predation over 10 days was highest in Kristianstad and Mälardalen and lower in the other study areas (Figure 5, Table 2). Further analysis showed the probability of daily predation on the artificial nest over 10 days was positively correlated to the mean count of corvids (Pearson $\mathrm{r}=0.84, n=5, p=0.037$, one-tailed test; Figure 6). However, there was no significant correlation between the density of raptors and the daily probability of nest predation (Pearson rank $\mathrm{r}=0.61, n=5, p=0.135$, one-tailed test; Figure 6). There was a strong relationship (Pearson $\mathrm{r}=0.99, n=5, p=0.0005$, one-tailed test) between the daily probability of nest predation over five and ten days, respectively, for the five case study areas.

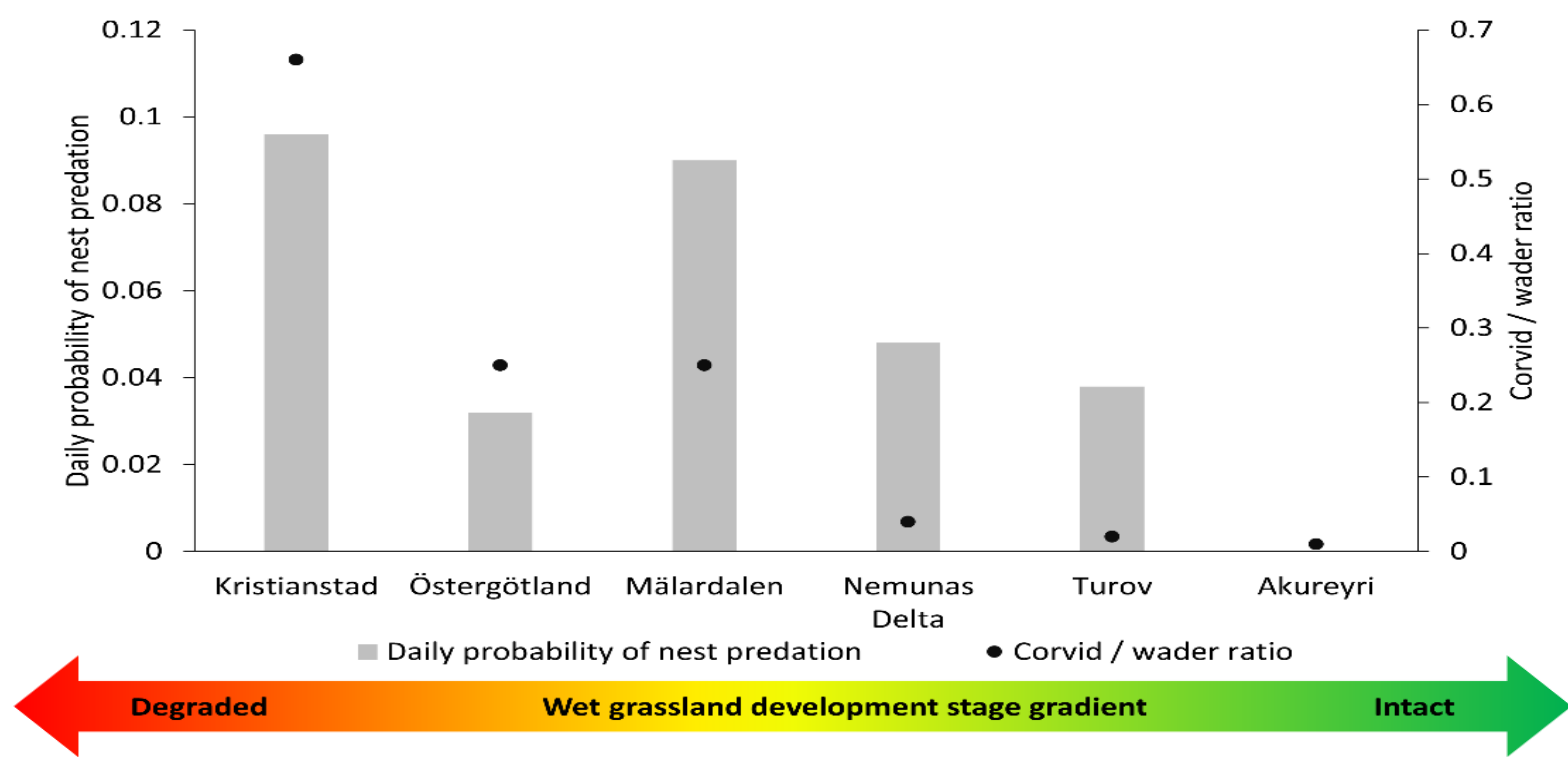

Figure 5. The daily probability of nest predation (grey bars) and avian predator ratio of corvids to waders (black circles) observed across the wet grassland development stages. Note: the nest predation experiment failed in Akureyri. 

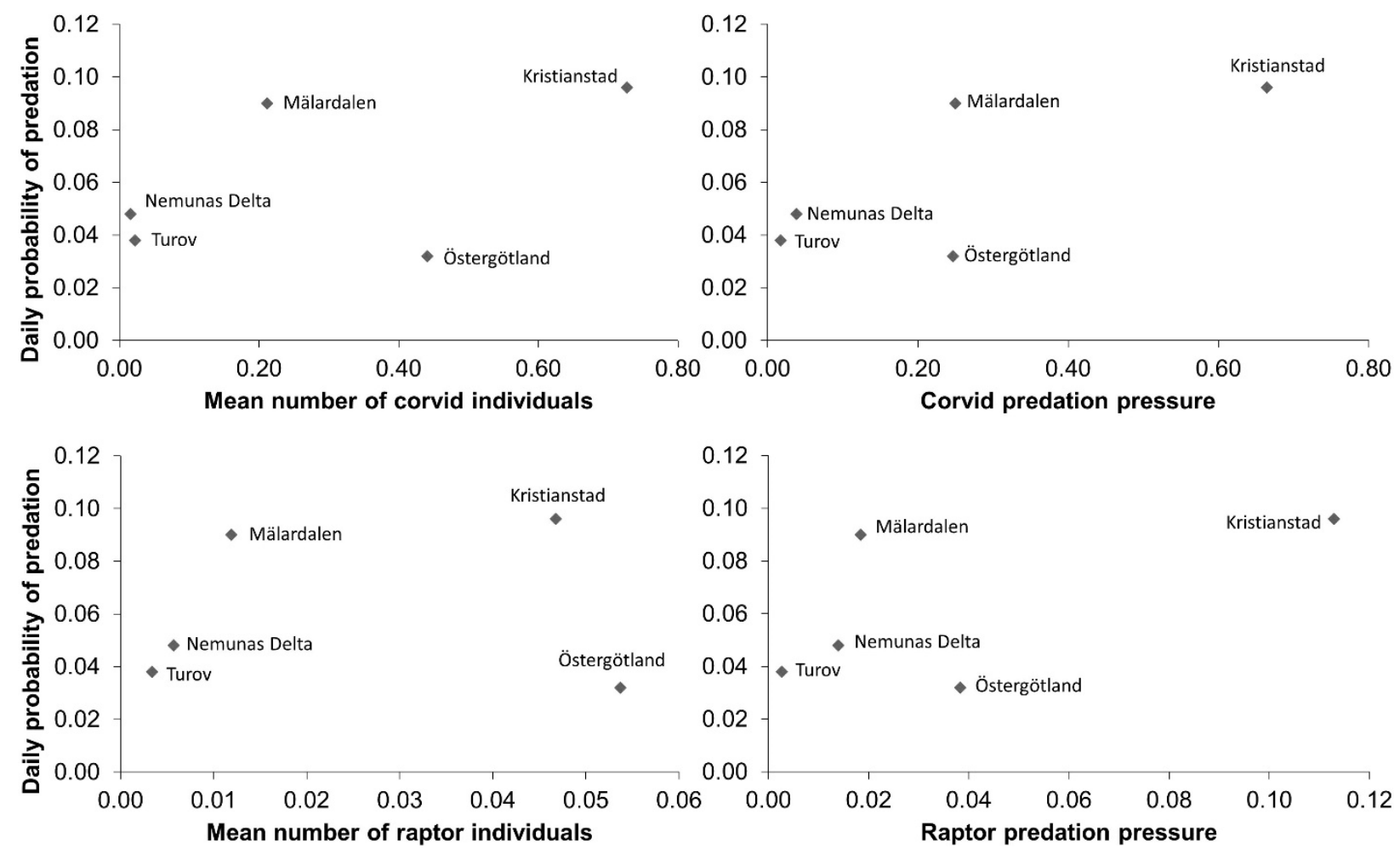

Figure 6. The relationship between corvid birds (top) and raptors (bottom) using mean number of individuals per hectare (left) and an estimate of predation pressure (right) and the daily probability of nest predation for the five study areas where the artificial nest experiments were conducted in northern Europe (Kristianstad, Östergötland, Mälardalen, Nemunas Delta and Turov; see Figure 1). Note: as the nest predation experiment failed in Akureyri, it was not plotted.

\section{Discussion}

\subsection{Clear Macroecological Patterns across Landscapes}

Our effort to apply a macroecological approach to explore the role of nest predation for sustaining viable populations of wader birds demonstrated clear differences among the wet grassland landscapes studied across Europe. First, while wader bird species richness was similar across the six landscapes, we found an inverse relationship between the mean number of observations of waders and corvid predators, as well as between the number of wader and corvid individuals. The relative abundance of corvid predators to waders decreased along the developmental stage gradient of wet grassland landscapes from emerging (Iceland) to functioning (Belarus) to degraded (Sweden).

Second, as predicted, the predation on artificial nests was considerably higher for the intensively managed landscapes of Sweden compared to the landscapes of Lithuania and Belarus. The probability of daily egg predation ranged from a high of 0.13 in Kristianstad to a low of 0.036 in Turov. This is consistent with previous studies suggesting increasing predator density and predation pressure from less to more intensively used landscapes [31,42,96]. In a review on nest predation, Macdonald and Bolton [92] found that $45 \%$ of predation events could not be identified $(n=1969)$. In our study, the role of avian predators versus unknown reasons for loss of artificial nests exhibited a clear gradient, paralleling the gradients of wader habitat and population change among the five landscapes studied.

Third, the predation rate on nests was correlated to the density of corvid birds, as well as to the wet grassland landscape development gradient between Europe's west and east. Indeed, corvids are well adapted to land use intensification and development as this generates higher food availability compared to landcovers in a more natural state [42]. Thus, this can be linked to corvids being opportunistic and generalist predators and raptors being more specialised predators. Moreover, the species richness of corvids and 
raptors was negatively correlated [42]. Our results in the north European macroecological gradient are supported by other comparative studies. In Iceland, where our nest predation experiment failed, Laidlaw, et al. [97] monitored 469 wader nests in 2015 and 2016, of which $\sim 40 \%$ were predated. Groen, et al. [98] and Kentie, Both, Hooijmeijer and Piersma [33] also demonstrated lower wader nest predation patterns (daily predation probability of 0.025 ) in favourable semi-natural grasslands compared to unfavourable intensified grassland monocultures (0.045) in Friesland, Netherlands. Chicks that hatched on semi-natural grasslands versus monoculture grasslands had apparent survival rates of 0.14 versus 0.06 , respectively [99]. Our own unpublished avian predator and wader counts from within the same grassland meadows and monocultures in the Netherlands parallel this pattern. Counts in May 2015 showed that the mean number of predators per wader individual was $1 / 379=0.003$ on semi-natural grasslands and $355 / 120=3.0$ on monocultures .

Finally, our results show that the relationship between waders and raptors was not statistically significant, but that does not mean that raptors have no biological effect. Indeed, there is evidence that conservation measures to increase raptor abundance can also have undesirable effects. Within the Kristianstad landscape, winter feeding programs and successful implementation of nesting infrastructure has helped increase raptor numbers but at the same time also increased the predation of wader bird chicks and adults [20]. This is consistent with the behavioural differences between raptors and corvids (nest predators). Similarly in Lithuania, the white-tailed eagle (Haliaeetus albicilla) population increased from the abyss of local extinction in 1985 to 120 breeding pairs in 2011 [100]. Such great conservation success stories are also widely implicated in local declines of ground nesting birds and may simply reflect a return to a more "natural" ecological baseline as raptor populations recover from decades of persecution and chemical pollutants [101]. This highlights the need for a systems analysis approach that views wet grasslands as social-ecological systems [70,102].

Although this study focused on avian predator assemblages and waders, we acknowledge that the same mechanism applies to both avian and mammalian predators. Mammalian predation has been shown to be important in influencing wader nest survival elsewhere in Europe [48,103-105] and the generalist diet mammals such as Red Fox (Vulpes vulpes) contribute to the predation of eggs and chicks [92,106,107]. For instance, a literature review of predation on wader nests in Europe found that mammals accounted for $70 \%$ of nest predation [92], and we hypothesise that this pattern is linked to a decreased role of generalist mammals along the landscape development gradient from unfavourable to favourable habitats. Perhaps this is because mammalian predators are rare on some study sites, or merely because avian predators are easier to monitor. Mammalian predation is also harder to identify [94], and mammalian predators also benefit from habitat degradation, similar to the mechanisms of avian predators [42]. Thus, the unknown nest predation result, can be considered of equal importance to that of the avian predation results. Moreover, the unknow nest predation result could be due to either mammalian or avian predation or something else.

Summarising, this study does not reject the hypothesis that landscapes differ in terms of nest predator abundance, and that nest predator abundance and nest predation are positively related. This highlights the importance of understanding and managing predator-prey relationships for the conservation of functional wet grassland patches and landscapes. We conclude that landscapes can be linked to the developmental stages of habitats from natural via anthropogenic induced wet grasslands to degraded ones (Figure 1). However, because there are many potential biases associated with the use of artificial nests that can make interpretation of trend data difficult [108], we recommend using artificial nests primarily in explorative and comparative studies.

\subsection{Small and Broad Scale Perspectives in Space and Time}

In general, nest predation is cited as the major cause of most nest failures and as a major constraint of successful wader bird breeding [92]. Predation as a factor behind 
breeding wader decline indeed calls for macroecological studies that trade off the precision of small-scale research of local habitat patches with a spatial scale that reflects regional landscape development stages [52]. For example, breeding waders typically utilise local homogenous patches, while corvid birds and especially raptors utilise entire landscapes containing a mixture of land cover mosaics. This also applies to mammal predators. Thus, similar macroecological studies which investigate the roles of mammal predators are needed.

Studies of the links between local ecological processes and large-scale patterns are recognized as one of the key avenues of research towards understanding species occurrence can facilitate improved predictions of future land use change conditions and species occurrence [23,53]. There are, thus, direct and indirect effects of reduced wet grassland quality and patch size within landscapes, and processes other than predation. Land cover change and shifts in landscape patterns can affect ecological processes. For example, habitat loss and fragmentation lead to edge effects [109-111], which can change the process of predation and thus influence species' distribution, behaviour and abundance. Declines in wader populations have most commonly been linked to factors such as loss of habitat, reduced open space surrounding habitat patches [18,112], intensification of grassland management, hydrological changes including drainage [9], and eutrophication of aquatic and wetland systems [113]. In addition, the shift from grazing to mowing grasslands results in a more homogeneous land cover and can also influence the breeding and survival of waders [114]. All these factors negatively influence the vegetation quantity and quality of wet grassland land covers as habitats for waders [48].

There are also other links between landscape pattern and predation risk. For example, Seymour, et al. [115] suggest that reduced wader numbers in a patch could lead to reduced effectiveness of active adult defence against nest and chick predation and that smaller populations of waders may be more susceptible to predation. One behavioural tactic waders may use is to forage in larger open sites, such as extensive grasslands, which provide safety for feeding and roosting, rather than smaller patches surrounded by vegetation, which facilitates crafty approaches by avian predators [116]. The proximity of trees and forests to wet grassland habitat patches offers cover to both avian and mammal predators [88,117].

Opportunities exist to support the macroecological approach with historical data, in other words to replace space with time in order to capture complex landscape transitions that take a long time to develop. For example, populations of both corvids and raptors have increased over the past 30 years throughout Europe [e.g., 8]. These population shifts have been caused by changes in land cover patterns and ecological processes linked to anthropogenic modification, as well as hunting bans and reduced use of chemicals in agriculture $[18,112]$. However, this approach is often limited by the availability of data spanning a long time period. A unique exception is the monitoring of raptor observations at Tipperne in Denmark 1930-2011, where Meltofte and Amstrup [118] concluded that almost all raptor species have increased on the reserve.

In closing, macroecological case study landscapes should vary in structure, such as habitat type and quality and species assemblages, as well as portfolios of processes which are linked to different landscape histories [42,51]. Ideally, these should also include a range of social systems that vary in their opportunity for landscape stewardship $[41,74,119]$ to manage and restore wet grasslands for waders. Key variables are types of landscape stewardship and management approaches that include wet grasslands with both unfavourable and favourable conservation status for waders. Learning about the historical range of variability of different types and amounts of land cover can thus be enhanced by combining macroecological and landscape history approaches. It is clear that public choice among intensive agriculture, human well-being, bird watching, and conservation of viable wader bird populations all matter. 


\section{Conclusions}

This exploratory study reveals a clear macroecological pattern with an inverse relationship between wader birds and corvid birds, and a positive relationship between corvid predator abundance and the rate of nest predation. We conclude that (a) habitat quality drives wader bird abundance directly (degradation means that habitats become less suitable for nesting and chick rearing); (b) habitat quality also drives predator abundance (degradation favors avian predator populations); and (c) habitat quality also therefore drives wader bird nest predation, which acts as a secondary more indirect driver of wader abundance. Degradation means more predators $=$ higher nest predation rates $=$ fewer chicks hatching and fledging $=$ fewer new recruits to future breeding populations $=$ population decline. Thus, this study illustrates the cumulative effects of habitat patterns, avian predators and nest predation on wader bird distribution and abundance. It also provides a clear conservation message that in some social-ecological contexts generalist predator populations need to be monitored and managed. Finally, the macroecological use of multiple landscapes spanning regions and countries with different landscape development trajectories can provide a broader perspective on what needs to be considered to maintain functional habitat networks such as wet grasslands through governance and management of the patterns and processes of social-ecological systems.

Supplementary Materials: The following are available online at https://www.mdpi.com/article/10

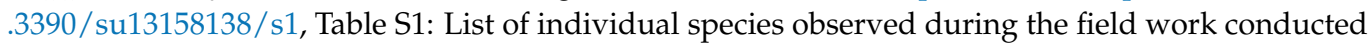
in six landscapes in northern Europe.

Author Contributions: Conceptualization, M.M. and P.A.; methodology, M.M. and P.A.; formal analysis, M.M. and P.A.; resources, M.M. and P.A.; writing—original draft preparation, M.M. and P.A.; writing - review and editing, M.M. and P.A.; visualization, M.M. and P.A.; funding acquisition, P.A. and M.M. All authors have read and agreed to the published version of the manuscript.

Funding: This study was made with funding from the Swedish Research Council FORMAS (grant number 2011-1737 and 2017-1342) to Per Angelstam.

Institutional Review Board Statement: Not applicable.

Informed Consent Statement: Not applicable.

Data Availability Statement: Data is contained within the article and Supplementary Materials.

Acknowledgments: We thank several anonymous reviewers for valuable comments on the manuscript.

Conflicts of Interest: The authors declare no conflict of interest. The founding sponsors had no role in the design of the study; in the collection, analyses, or interpretation of data; in the writing of the manuscript; or in the decision to publish the results.

\section{References}

1. Joyce, C.; Wade, P. Wet Grasslands: A European Perspective; John Wiley: Chichester, UK, 1998; p. 340.

2. Benstead, P.; Drake, M.; Jose, P.; Mountford, O.; Newbold, C.; Treweek, J. The Wet Grassland Guide; Royal Society for the Protection of Birds: Sandy, UK, 1997.

3. Price, E. Lowland Grassland and Heathland Habitats; Routledge: London, UK, 2003.

4. Antrop, M. The transformation of the Mediterranean landscapes: An experience of 25 years of observations. Landsc. Urban Plan. 1993, 24, 3-13. [CrossRef]

5. Hartel, T.; Plieninger, T. European Wood-Pastures in Transition: A Social-Ecological Approach; Routledge: London, UK, 2014.

6. Benstead, P.; Jose, P.; Joyce, C.; Wade, P. European Wet Grassland: Guidelines for Management and Restoration; RSPB: Sandy, UK, 1999.

7. Newton, I. The recent declines of farmland bird populations in Britain: An appraisal of causal factors and conservation actions. IBIS 2004, 146, 579-600. [CrossRef]

8. Schekkerman, H.; Teunissen, W.; Oosterveld, E. The effect of 'mosaic management' on the demography of Black-tailed Godwit Limosa limosa on farmland. J. Appl. Ecol. 2008, 45, 1067-1075. [CrossRef]

9. Beintema, A.J. Man-made polders in the netherlands: A traditional habitat for shorebirds. Colonial Waterbirds 1986, 9, 196-202. [CrossRef]

10. Brinson, M.M.; Malvárez, A. Temperate freshwater wetlands: Types, status, and threats. Environ. Conserv. 2002, 29, 115-133. [CrossRef] 
11. Illyés, E.; Botta-Dukát, Z.; Molnár, Z. Patch and landscape factors affecting the naturalness-based quality of three model grassland habitats in Hungary. Acta Bot. Hung. 2008, 50, 179-197. [CrossRef]

12. Durant, D.; Tichit, M.; Kernéïs, E.; Fritz, H. Management of agricultural wet grasslands for breeding waders: Integrating ecological and livestock system perspectives-A review. Biodivers. Conserv. 2008, 17, 2275-2295. [CrossRef]

13. Catry, T.; Alves, J.A.; Andrade, J.; Costa, H.; Dias, M.P.; Fernandes, P.; Leal, A.; Lourenco, P.M.; Martins, R.C.; Moniz, F.; et al. Long-term declines of wader populations at the Tagus estuary, Portugal: A response to global or local factors? Bird Conserv. Int. 2011, 21, 438-453. [CrossRef]

14. Roodbergen, M.; Werf, B.; Hötker, H. Revealing the contributions of reproduction and survival to the Europe-wide decline in meadow birds: Review and meta-analysis. J. Ornithol. 2011, 153, 53-74. [CrossRef]

15. Gill, J.A.; Langston, R.H.W.; Alves, J.A.; Atkinson, P.W.; Bocher, P.; Cidraes Vieira, N.; Crockford, N.J.; Gélinaud, G.; Groen, N.; Gunnarsson, T.G.; et al. Contrasting trends in two Black-tailed Godwit populations: A review of causes and recommendations. Wader Study Group Bull. 2007, 114, 43-50.

16. Schekkerman, H.; Teunissen, W.; Oosterveld, E. Mortality of Black-tailed Godwit Limosa limosa and Northern Lapwing Vanellus vanellus chicks in wet grasslands: Influence of predation and agriculture. J. Ornithol. 2009, 150, 133-145. [CrossRef]

17. Thorup, O. Breeding waders in Europe 2000. In International Wader Studies; Wader Study Group: Thetford, UK, 2005 ; Volume 14.

18. Ottvall, R.; Edenius, L.; Elmberg, J.; Engström, H.; Green, M.; Holmqvist, N.; Lindström, Å.; Pärt, T.; Tjernberg, M. Population trends for Swedish breeding birds. Ornis Svec. 2009, 19, 117-192.

19. Lindström, Å.; Green, M. Monitoring Population Changes of Birds in Sweden. Annual Report for 2012; Department of Biology, Lund University: Lund, Sweden, 2013; 80p.

20. Manton, M.; Angelstam, P.; Milberg, P.; Elbakidze, M. Wet grasslands as a green infrastructure for ecological sustainability: Wader conservation in Southern Sweden as a case study. Sustainability 2016, 8, 340. [CrossRef]

21. Bergner, A. Fåglar på Strandängar i Östergötland-Inventeringar 1996-2013; Länsstyrelsen Östergötland: Linköping, Sweden, 2013.

22. Nilsson, S. Skandinavisk Fauna. Foglarna. Första Bandet; Gleerups: Lund, Sweden, 1858.

23. Turner, M.G. Landscape ecology: The effect of pattern on process. Annu. Rev. Ecol. Syst. 1989, 20, 171-197. [CrossRef]

24. Gustafson, E.J. Quantifying landscape spatial pattern: What is the state of the art? Ecosystems 1998, 1, 143-156. [CrossRef]

25. Ward, J.V.; Malard, F.; Tockner, K. Landscape ecology: A framework for integrating pattern and process in river corridors. Landsc. Ecol. 2002, 17, 35-45. [CrossRef]

26. Forman, R.T. Some general principles of landscape and regional ecology. Landsc. Ecol. 1995, 10, 133-142. [CrossRef]

27. Nagendra, H.; Munroe, D.K.; Southworth, J. From pattern to process: Landscape fragmentation and the analysis of land use/land cover change. Agric. Ecosyst. Environ. 2004, 101, 111-115. [CrossRef]

28. Tuvendal, M.; Elmqvist, T. Ecosystem services linking social and ecological systems: River brownification and the response of downstream stakeholders. Ecol. Soc. 2011, 16, 21. [CrossRef]

29. Lindenmayer, D.B.; Fischer, J. Habitat Fragmentation and Landscape Change: An Ecological and Conservation Synthesis; Island Press: Washington, DC, USA, 2006; p. 329.

30. Ives, A.R.; Cardinale, B.J.; Snyder, W.E. A synthesis of subdisciplines: Predator-prey interactions, and biodiversity and ecosystem functioning. Ecol. Lett. 2005, 8, 102-116. [CrossRef]

31. Andrén, H.; Angelstam, P.; Lindström, E.; Widén, P. Differences in predation pressure in relation to habitat fragmentation: An experiment. Oikos 1985, 45, 273-277. [CrossRef]

32. Angelstam, P. Predation on Ground-Nesting Birds' Nests in Relation to Predator Densities and Habitat Edge. Oikos 1986, 47, 365-373. [CrossRef]

33. Kentie, R.; Both, C.; Hooijmeijer, J.C.E.W.; Piersma, T. Management of modern agricultural landscapes increases nest predation rates in Black-tailed Godwits Limosa limosa. IBIS 2015, 157, 614-625. [CrossRef]

34. Amar, A.; Thirgood, S.; Pearce-Higgins, J.; Redpath, S. The impact of raptors on the abundance of upland passerines and waders. Oikos 2008, 117, 1143-1152. [CrossRef]

35. Loman, J.; Göransson, G. Egg shell dumps and Crow Corvus cornix predation on simulated birds' nests. Oikos 1978, 30, 461-466. [CrossRef]

36. Cronert, H. Strandängsfåglar i Vattenriket. Häckfågelkarteringarna och simultanräkningar. Spoven 2014, 1, 1-19.

37. Pehlak, H.; Lõhmus, A. An artificial nest experiment indicates equal nesting success of waders in coastal meadows and mires. Ornis Fenn. 2008, 85, 66-71.

38. Martin, T.E. Processes organizing open-nesting bird assemblages: Competition or nest predation? Evol. Ecol. 1988, 2, 37-50. [CrossRef]

39. Angelstam, P.; Axelsson, R.; Elbakidze, M.; Laestadius, L.; Lazdinis, M.; Nordberg, M.; Pătru-Stupariu, I.; Smith, M. Knowledge production and learning for sustainable forest management on the ground: Pan-European landscapes as a time machine. Forestry 2011, 84, 581-596. [CrossRef]

40. Angelstam, P.; Manton, M.; Yamelynets, T.; Fedoriak, M.; Albulescu, A.-C.; Bravo, F.; Cruz, F.; Jaroszewicz, B.; Kavtarishvili, M.; Muñoz-Rojas, J.; et al. Maintaining natural and traditional cultural green infrastructures across Europe: Learning from historic and current landscape transformations. Landsc. Ecol. 2021, 36, 637-663. [CrossRef] 
41. Angelstam, P.; Fedoriak, M.; Cruz, F.; Muñoz-Rojas, J.; Yamelynets, T.; Manton, M.; Washbourne, C.-L.; Dobrynin, D.; Izakovicova, Z.; Jansson, N.; et al. Meeting places and social capital supporting rural landscape stewardship: A Pan-European horizon scanning. Ecol. Soc. 2021, 26. [CrossRef]

42. Manton, M.; Angelstam, P.; Naumov, V. Effects of Land Use Intensification on Avian Predator Assemblages: A Comparison of Landscapes with Different Histories in Northern Europe. Diversity 2019, 11, 70. [CrossRef]

43. Papworth, S.; Rist, J.; Coad, L.; Milner-Gulland, E. Evidence for shifting baseline syndrome in conservation. Conserv. Lett. 2009, 2, 93-100. [CrossRef]

44. Pauly, D. Anecdotes and the shifting baseline syndrome of fisheries. Trends Ecol. Evol. 1995, 10, 430. [CrossRef]

45. Jongman, R.H.G.; Bouwma, I.M.; Griffioen, A.; Jones-Walters, L.; Van Doorn, A.M. The Pan European Ecological Network: PEEN. Landsc. Ecol. 2011, 26, 311-326. [CrossRef]

46. Wiens, J.A. Spatial scaling in ecology. Funct. Ecol. 1989, 3, 385-397. [CrossRef]

47. Hall, L.S.; Krausman, P.R.; Morrison, M.L. The habitat concept and a plea for standard terminology. Wildl. Soc. Bull. 1997, 25, 173-182.

48. Eglington, S.M.; Gill, J.A.; Smart, M.A.; Sutherland, W.J.; Watkinson, A.R.; Bolton, M. Habitat management and patterns of predation of Northern Lapwings on wet grasslands: The influence of linear habitat structures at different spatial scales. Biol. Conserv. 2009, 142, 314-324. [CrossRef]

49. Manton, M.; Angelstam, P. Defining Benchmarks for Restoration of Green Infrastructure: A Case Study Combining the Historical Range of Variability of Habitat and Species' Requirements. Sustainability 2018, 10, 326. [CrossRef]

50. Dunning, J.B.; Danielson, B.J.; Pulliam, H.R. Ecological processes that affect populations in complex landscapes. Oikos 1992, 65, 169-175. [CrossRef]

51. Roberge, J.-M.; Angelstam, P.; Villard, M.-A. Specialised woodpeckers and naturalness in hemiboreal forests-Deriving quantitative targets for conservation planning. Biol. Conserv. 2008, 141, 997-1012. [CrossRef]

52. Brown, J.H. Macroecology; University of Chicago Press: Chicago, IL, USA, 1995; p. 284.

53. Beck, J.; Ballesteros-Mejia, L.; Buchmann, C.M.; Dengler, J.; Fritz, S.A.; Gruber, B.; Hof, C.; Jansen, F.; Knapp, S.; Kreft, H.; et al. What's on the horizon for macroecology? Ecography 2012, 35, 673-683. [CrossRef]

54. Plieninger, T.; Kizos, T.; Bieling, C.; Le Dû-Blayo, L.; Budniok, M.-A.; Bürgi, M.; Crumley, C.L.; Girod, G.; Howard, P.; Kolen, J. Exploring ecosystem-change and society through a landscape lens: Recent progress in European landscape research. Ecol. Soc. 2015, 20, 5. [CrossRef]

55. Eisenhardt, K.M. Building theories from case study research. Acad. Manag. Rev. 1989, 14, 532-550. [CrossRef]

56. Flyvbjerg, B. Case Study. In The Sage Handbook of Qualative Research, 4th ed.; Denzin, N.K., Lincoln, Y.S., Eds.; Sage: Thousand Oaks, CA, USA, 2011; pp. 301-316.

57. Stake, R.E. The Art of Case Study Research; Sage: London, UK, 1995.

58. Yin, R.K. The case study crisis: Some answers. Adm. Sci. Q. 1981, 26, 58-65. [CrossRef]

59. Angelstam, P.; Dönz-Breuss, M. Measuring forest biodiversity at the stand scale: An evaluation of indicators in European forest history gradients. Ecol. Bull. 2004, 51, 305-332. [CrossRef]

60. Puumalainen, J.; Kennedy, P.; Folving, S. Monitoring forest biodiversity: A European perspective with reference to temperate and boreal forest zone. J. Environ. Manag. 2003, 67, 5-14. [CrossRef]

61. Angelstam, P.; Roberge, J.M.; Lõhmus, A.; Bergmanis, M.; Brazaitis, G.; Dönz-Breuss, M.; Edenius, L.; Kosinski, Z.; Kurlavicius, P.; Lārmanis, V.; et al. Habitat modelling as a tool for landscape-scale conservation: A review of parameters for focal forest birds. Ecol. Bull. 2004, 51, 427-453. [CrossRef]

62. Åberg, J.; Swenson, J.E.; Angelstam, P. The habitat requirements of hazel grouse (Bonasa bonasia) in managed boreal forest and applicability of forest stand descriptions as a tool to identify suitable patches. For. Ecol. Manag. 2003, 175, 437-444. [CrossRef]

63. Valasiuk, S.; Giergiczny, M.; Żylicz, T.; Klimkowska, A.; Angelstam, P. Conservation of disappearing cultural landscape's biodiversity: Are people in Belarus willing to pay for wet grassland restoration? Wetl. Ecol. Manag. 2018, 26, 943-960. [CrossRef]

64. Waldén, B. Den Stora Sjösänkningen; Aktiebolaget Littorin Rydén boktryckerip: Örebro, Sweden, 1940; p. 366.

65. Palmqvist, L.A. Bruket Av Våtängarna Vid Nötmyran Västerfärnebo Socken: Ängsbruket Och Bebyggelsen i Hedbo by; Nordiska Museet: Stockholm, Sweden, 1980; p. 60.

66. Food and Agriculture Organization. FAO Statistical Yearbook 2014; FAO Regional Office for Europe and Central Asia: Budapest, Hungary, 2014.

67. Berg, ̊.; Jonsson, M.; Lindberg, T.; Källebrink, K.-G. Population dynamics and reproduction of Northern Lapwings Vanellus vanellus in a meadow restoration area in central Sweden. IBIS 2002, 144, 131-140. [CrossRef]

68. International, B. Birds of Europe: Population Estimates, Trends and Conservation Status; BirdLife International: Cambridge, UK, 2004.

69. Ottosson, U.; Ottvall, R.; Elmberg, J.; Green, M.; Gustafsson, R.; Haas, F.; Holmqvist, N.; Lindström, Å.; Nilsson, L.; Svensson, M.; et al. Fåglarna i Sverige-Antal Och Förekomst; SOF: Halmstad, Sweden, 2012.

70. Dawson, L.; Elbakidze, M.; Angelstam, P.; Gordon, J. Governance and management dynamics of landscape restoration at multiple scales: Learning from successful environmental managers in Sweden. J. Environ. Manag. 2017, 197, 24-40. [CrossRef] [PubMed]

71. Bergman, K.-O.; Dániel-Ferreira, J.; Milberg, P.; Öckinger, E.; Westerberg, L. Butterflies in Swedish grasslands benefit from forest and respond to landscape composition at different spatial scales. Landsc. Ecol. 2018, 33, 2189-2204. [CrossRef] 
72. Lindborg, R.; Eriksson, O. Historical landscape connectivity affects present plant species diversity. Ecology 2004, 85, 1840-1845. [CrossRef]

73. Magnusson, S.-E.; Magntorn, K.; Wallsten, E.; Cronert, H.; Thelaus, M. Kristianstads Vattenrike Biosphere Reserve Nomination Form; Kristianstad Kommun: Kristianstad, Sweden, 2004.

74. Angelstam, P.; Elbakidze, M. Forest landscape stewardship for functional green infrastructures in Europe's West and East: Diagnosing and treating social-ecological systems. In The Science and Practice of Landscape Stewardship; Bieling, C., Plieninger, T., Eds.; Cambridge University Press: Cambridge, UK, 2017; pp. 124-144.

75. Stanevičius, V.; Mačiulis, M.; Švažas, S. Breeding ecology of lapwing (Vanellus vanellus) in floodplains of the Nemunas River delta in 2006-2007. Ekologija 2008, 54, 10-16. [CrossRef]

76. Švažas, S.; Kozulin, A.; Grishanov, G.; Maximenkov, M.; Rašomavičius, V.; Raudonikis, L.; Baichorov, V.; Skuratovich, A.; Balčiauskas, L.; Drobelis, E.; et al. Important Transboundary Belarusian-Lithuanian and Lithuanian-Russian Wetlands; Akstis: Vilnius, Lithuania, 2003; p. 96.

77. Kurlavičius, P. Lithuanian breeding bird atlas. In Lithuanian Ornithological Society; Lututè: Švenčionys, Lithuania, 2006.

78. Thorup, O.; Preiksa, Z.; Pehlak, H.; Altemüller, M.; Drews, H. Status of the Baltic Dunlin Calidris alpina in Lithuania. Wader Study Group Bull. 2011, 118, 184-187.

79. Pinchuk, P.; Karlionova, N.; Zhurauliou, D. Wader ringing at the Turov ornithological station, Pripyat Valley (S Belarus) in 1996-2003. Ring 2005, 27, 101. [CrossRef]

80. Delany, S.; Scott, D.; Helmink, A. Waterbird population estimates. Wetl. Int. Glob. Ser. 2006, 12, 226.

81. Gunnarsson, T.G.; Gill, J.A.; Appleton, G.F.; Gíslason, H.; Gardarsson, A.; Watkinson, A.R.; Sutherland, W.J. Large-scale habitat associations of birds in lowland Iceland: Implications for conservation. Biol. Conserv. 2006, 128, 265-275. [CrossRef]

82. Gunnarsson, T.G.; Gill, J.A.; Potts, P.M.; Atkinson, P.W.; Croger, R.E.; Gélinaud, G.; Gardarsson, A.; Sutherland, W.J. Estimating population size in Black-tailed Godwits Limosa limosa islandica by colour-marking. Bird Study 2005, 52, 153-158. [CrossRef]

83. Jóhannesdóttir, L.; Alves, J.A.; Gill, J.A.; Gunnarsson, T.G. Reconciling biodiversity conservation and agricultural expansion in the subarctic environment of Iceland. Ecol. Soc. 2017, 22. [CrossRef]

84. Robinson, W.D.; Styrsky, J.N.; Brawn, J.D. Are Artificial Bird Nests Effective Surrogates for Estimating Predation on Real Bird Nests? A Test With Tropical Birds. Auk 2005, 122, 843-852. [CrossRef]

85. Faaborg, J. Truly artificial nest studies. Conserv. Biol. 2004, 18, 369-370. [CrossRef]

86. Zanette, L. What do artificial nests tells us about nest predation? Biol. Conserv. 2002, 103, 323-329. [CrossRef]

87. Major, R.E.; Kendal, C.E. The contribution of artificial nest experiments to understanding avian reproductive success: A review of methods and conclusions. IBIS 1996, 138, 298-307. [CrossRef]

88. Andrén, H.; Angelstam, P. Elevated predation rates as an edge effect in habitat islands: Experimental evidence. Ecology 1988, 69, 544-547. [CrossRef]

89. Davison, W.B.; Bollinger, E. Predation Rates on Real and Artificial Nests of Grassland Birds. Auk 2000, 117, 147-153. [CrossRef]

90. Villard, M.-A.; Part, T. Don't put all your eggs in real nests: A sequel to Faaborg. Conserv. Biol. 2004, 18, 371-372. [CrossRef]

91. Mandema, F.S.; Tinbergen, J.M.; Ens, B.J.; Bakker, J.P. Livestock grazing and trampling of birds' nests: An experiment using artificial nests. J. Coast. Conserv. 2013, 17, 409-416. [CrossRef]

92. Macdonald, M.A.; Bolton, M. Predation on wader nests in Europe. IBIS 2008, 150, 54-73. [CrossRef]

93. Mason, L.R.; Smart, J.; Drewitt, A.L. Tracking day and night provides insights into the relative importance of different wader chick predators. IBIS 2017, 160, 71-88. [CrossRef]

94. Green, R.E.; Hawell, J.; Johnson, T.H. Identification of predators of wader eggs from egg remains. Bird Study 1987, 34, 87-91. [CrossRef]

95. Mayfield, H.F. Suggestions for calculating nest success. Wilson Bull. 1975, 87, 456-466.

96. Andrén, H. Corvid density and nest predation in relation to forest fragmentation: A landscape perspective. Ecology 1992, 73, 794-804. [CrossRef]

97. Laidlaw, R.A.; Gunnarsson, T.G.; Méndez, V.; Carneiro, C.; Pórisson, B.; Wentworth, A.; Gill, J.A.; Alves, J.A. Vegetation structure influences predation rates of early nests in subarctic breeding waders. IBIS 2020, 162, 1225-1236. [CrossRef]

98. Groen, N.M.; Kentie, R.; Goeij, P.d.; Verheijen, B.; Hooijmeijer, J.C.E.W.; Piersma, T. A modern landscape ecology of Black-Tailed Godwits: Habitat selection in Southwest Friesland, the Netherlands. Ardea 2012, 100, 19-28. [CrossRef]

99. Kentie, R. Spatial Demography of Black-Tailed Godwits: Metapopulation Dynamics in a Fragmented Agricultural Landscape Ph.D. Thesis, University of Groningen, Groningen, The Netherlands, 2015.

100. Treinys, R.; Dementavičius, D.; Rumbutis, S.; Švažas, S.; Butkauskas, D.; Sruoga, A.; Dagys, M. Settlement, habitat preference, reproduction, and genetic diversity in recovering the white-tailed eagle Haliaeetus albicilla population. J. Ornithol. 2016, 157, 311-323. [CrossRef]

101. Hipfner, M.J.; Blight, L.K.; Lowe, R.W.; Wilhelm, S.I.; Robertson, G.J.; Barrett, R.T.; Anker-Nilssen, T.; Good, T.P. Unintended consequences: How the recovery of sea eagle Haliaeetus spp. populations in the northern hemisphere is affecting seabirds. Mar. Ornithol. 2012, 40, 39-52.

102. Dawson, L.; Elbakidze, M.; Schellensac, M.; Shkarubad, A.; Angelstam, P. Bogs, Birds and Berries in Belarus: The governance and management dynamics of wetland restoration in a state-centric, top-down context. Ecol. Soc. 2021, 26, 8. [CrossRef] 
103. Teunissen, W.; Schekkerman, H.; Willems, F.; Majoor, F. Identifying predators of eggs and chicks of Lapwing Vanellus vanellus and Black-tailed Godwit Limosa limosa in the Netherlands and the importance of predation on wader reproductive output. IBIS 2008, 150, 74-85. [CrossRef]

104. Laidlaw, R.A.; Smart, J.; Smart, M.A.; Gill, J.A. Managing a food web: Impacts on small mammals of managing grasslands for breeding waders. Anim. Conserv. 2013, 16, 207-215. [CrossRef]

105. Rickenbach, O.; Grüebler, M.U.; Schaub, M.; Koller, A.; Naef-Daenzer, B.; Schifferli, L. Exclusion of ground predators improves Northern Lapwing Vanellus vanellus chick survival. IBIS 2011, 153, 531-542. [CrossRef]

106. Laidlaw, R.A.; Smart, J.; Smart, M.A.; Gill, J.A. The influence of landscape features on nest predation rates of grassland-breeding waders. IBIS 2015, 157, 700-712. [CrossRef]

107. Jackson, D.B. Experimental removal of introduced hedgehogs improves wader nest success in the Western Isles, Scotland. J. Appl. Ecol. 2001, 38, 802-812. [CrossRef]

108. Wilson, G.R.; Brittingham, M.C.; Goodrich, L.J. How Well do Artificial Nests Estimate Success of Real Nests? Condor 1998, 100, 357-364. [CrossRef]

109. Fuller, R.J. Avian Responses to Transitional Habitats in Temperate Cultural Landscapes: Woodland Edges and Young-Growth. Birds and Habitat. Relationships in Changing Landscapes; Fuller, R.J., Ed.; Cambridge University Press: Cambridge, UK, 2012.

110. Berg, Å.; Wretenberg, J.; Żmihorski, M.; Hiron, M.; Pärt, T. Linking occurrence and changes in local abundance of farmland bird species to landscape composition and land-use changes. Agric. Ecosyst. Environ. 2015, 204, 1-7. [CrossRef]

111. Żmihorski, M.; Krupiński, D.; Kotowska, D.; Knape, J.; Pärt, T.; Obłoza, P.; Berg, Å. Habitat characteristics associated with occupancy of declining waders in Polish wet grasslands. Agric. Ecosyst. Environ. 2018, 251, 236-243. [CrossRef]

112. Rönkä, A. Distribution, status and population trends in the Temminck's Stint Calidris temminckii in the Finnish Bothnian Bay. Ornis Fenn. 1996, 73, 1-11.

113. Koivula, K.; Rönkä, A. Habitat deterioration and efficiency of antipredator strategy in a meadow-breeding wader, Temminck's stint (Calidris temminckii). Oecologia 1998, 116, 348-355. [CrossRef]

114. Tucker, G.M.; Davies, S.; Fuller, R. The Ecology and Conservation of Lapwings Vanellus Vanellus; Joint Nature Conservation Committee: Peterborough, UK, 1994.

115. Seymour, A.S.; Harris, S.; Ralston, C.; White, P.C.L. Factors influencing the nesting success of Lapwings Vanellus vanellus and behaviour of Red Fox Vulpes vulpes in Lapwing nesting sites. Bird Study 2003, 50, 39-46. [CrossRef]

116. Lank, D.B.; Butler, R.W.; Ireland, J.; Ydenberg, R.C. Effects of predation danger on migration strategies of sandpipers. Oikos 2003, 103, 303-319. [CrossRef]

117. Červinka, J.; Šálek, M.; Pavluvčík, P.; Kreisinger, J. The fine-scale utilization of forest edges by mammalian mesopredators related to patch size and conservation issues in Central European farmland. Biodivers. Conserv. 2011, 20, 3459-3475. [CrossRef]

118. Meltofte, H.; Amstrup, O. Forekomsten af rovfugle på Tipperne 1930-2011. Dan. Orn. Foren. Tidsskr. 2013, 107, $229-238$.

119. Herzon, I.; Raatikainen, K.J.; Wehn, S.; Rūsina, S.; Helm, A.; Cousins, S.A.O.; Rašomavičius, V. Semi-natural habitats in boreal Europe: A rise of a social-ecological research agenda. Ecol. Soc. 2021, 26. [CrossRef] 